Terbit online pada laman web jurnal : http://teknosi.fti.unand.ac.id/

Jurnal Nasional Teknologi dan Sistem Informasi

| ISSN (Print) 2460-3465 |ISSN (Online) 2476-8812|

Artikel Penelitian

\title{
Optimasi Prediksi Dengan Algoritma Backpropagation Dan Conjugate Gradient Beale-Powell Restarts
}

\author{
Anjar Wanto ${ }^{a}$ \\ ${ }^{a}$ STIKOM Tunas Bangsa, Jln. Jend. Sudirman Blok A No. 2 dan 3, Pematangsiantar 21111, Indonesia
}

\begin{tabular}{|c|}
\hline INFORMASIARTIKEL \\
\hline $\begin{array}{l}\text { Sejarah Artikel: } \\
\text { Diterima Redaksi: } 27 \text { Oktober } 2017 \\
\text { Revisi Akhir: 03 Januari } 2018 \\
\text { Diterbitkan Online: 04 Januari } 2018\end{array}$ \\
\hline KATA KUNCI \\
\hline Optimization \\
\hline Prediction \\
\hline Backpropagation \\
\hline Beale-Powell Restarts \\
\hline KORESPONDENSI \\
\hline Telepon: +62 82294365929 \\
\hline E-mail: anjarwanto@amiktunasbangsa.ac.id \\
\hline
\end{tabular}

\section{A B S T R A C T}

Optimization of a prediction (forecasting) is very important to do so that the predicted results obtained to be better and quality. In this study, the authors optimize previous research that has been done by the author using backpropagation algorithm. The optimization process will use Conjugate Gradient Beale-Powell Restarts. Data to be predicted is Consumer Price Index data based on health group from Medan Central Bureau of Statistics from 2014 until 2016. Previous research using 8 architectural models, namely: 12-5-1, 12-26-1, 12-29 -1, 12-35-1, 12-40-1, $12-$ $60-1,12-70-1$ and 12-75-1 with best architectural models 12-70-1 with an accuracy of $92 \%$. In contrast to previous research concentrating on finding accuracy using backpropagation, this study will optimize the backpropagation with Conjugate Gradient Beale-Powell Restart, which not only focuses on accuracy but also the convergence of the two algorithms and the translation of predicted results, which is not done in a previous study. This research will use the same architectural model as the previous research and will get the result with the accuracy of $92 \%$ with the best architectural model that is 12-70-1 (same as previous research). Thus, this model is good enough for prediction even with different algorithms, since the accuracy of converging backpropagation with Conjugate Gradient Beale-Powell Restarts.

\section{PENDAHULUAN}

\subsection{Latar Belakang}

Prediksi (peramalan) merupakan hal yang sangat penting dalam kehidupan manusia. Karena dengan melakukan prediksi, maka suatu masalah akan dapat diperkecil dampak yang akan terjadi kedepannya [1], terutama dalam bidang ekonomi. Pentingnya mengetahui kondisi perekonomian yang akan datang, menjadi kunci pergerakan arah siklus ekonomi. Dengan melakukan suatu prediksi, pengetahuan tentang posisi perekonomian Indonesia dapat diketahui sehingga dapat mengantisipasi atau meminimalisasi resiko yang mungkin akan ditimbulkan, sehingga baik pemerintah maupun pihak swasta dapat terbantu dalam menentukan kebijakan maupun pengambilan keputusan. Akan tetapi proses prediksi tidaklah mudah, dibutuhkan model dasar dan data rangkaian waktu dari masalah-masalah tersebut, yang umumnya rumit dengan cara estimasi keakuratan yang tidak mudah dicapai, sehingga membutuhkan teknik yang lebih maju [2].

https://doi.org/10.25077/ TEKNOSI.v3i3.2017.370-380
Salah satu teknik yang baik digunakan untuk prediksi adalah jaringan saraf tiruan backpropagation karena algoritma backpropagation memungkinkan untuk menghindari kesulitan yang dijelaskan menggunakan aturan belajar yang mirip dengan plastisitas lonjakan waktu yang tergantung pada sinapsis [3]. Namun Algoritma backpropagation ini cenderung lambat untuk mencapai konvergen dalam mendapatkan akurasi yang optimum [4], serta memerlukan data training yang besar dan optimasi yang digunakan kurang efisien [5]. Oleh karena itu dibutuhkan optimasi dengan menggunakan metode lain, agar keakuratan hasil yang didapatkan lebih baik, lebih cepat, dan dapat dipertanggungjawabkan bila dibandingkan dengan hanya menggunakan algoritma backpropagation standard saja.

Optimasi yang akan digunakan adalah metode Conjugate Gradient Beale-Powell Restarts. Metode ini sering digunakan untuk menyelesaikan masalah optimasi tak berkendala, baik untuk memecahkan sistem persamaan linear dan taklinear dengan skala besar [6]. Dalam algoritma ini, ukuran langkah dimodifikasi oleh fungsi pencarian pada setiap iterasi sehingga tercapai tujuan 
sedini mungkin dalam beberapa iterasi [7], sehingga hasil akurasi lebih cepat diperoleh.

Pada penelitian ini, data yang akan diprediksi adalah data Indeks Harga Konsumen (IHK) berdasarkan kelompok kesehatan yang berasal dari Badan Pusat Statistik Kota Medan dari tahun 2014 sampai 2016. Indeks Harga Konsumen (IHK) merupakan salah satu indikator ekonomi yang umum digunakan untuk mengukur tingkat perubahan harga (inflasi / deflasi) di tingkat konsumen, terutama di daerah perkotaan [8]. Penghitungan IHK ditujukan untuk mengetahui perubahan harga dari sekelompok tetap barang/jasa yang umumnya dikonsumsi oleh masyarakat setempat [9]. Salah satu IHK yang cukup penting adalah berdasarkan kelompok kesehatan. Karena kesehatan akan berimbas kepada kehidupan dan aktifitas masyarakat sehari-hari. Adapun kelompok pengeluaran dari Indeks Harga Konsumen dapat dilihat pada Tabel 1 berikut :

Tabel 1. Kelompok Pengeluaran Indeks Harga Konsumen

\begin{tabular}{cl}
\hline No & \multicolumn{1}{c}{ Uraian } \\
\hline 1 & Bahan Makanan \\
2 & Makanan Jadi, Minuman, Rokok Dan Tembakau \\
3 & Perumahan,Air, Listrik, Gas dan Bahan Bakar \\
4 & Sandang \\
5 & Kesehatan \\
6 & Pendidikan, Rekreasi dan Olahraga \\
7 & Transport, Komunikasi dan Jasa Keuangan \\
\hline Sumber : & Badan Pusat Statistik Pematangsiantar)
\end{tabular}

Berdasarkan tabel 1, bahwa setiap sektor terdiri dari beberapa subkelompok. Adapun data subkelompok dari setiap sektor Indeks Harga Konsumen dapat dilihat pada tabel 2. berikut :

Tabel 2. Sub Kelompok Pengeluaran Indeks Harga Konsumen

\begin{tabular}{|c|c|c|}
\hline No & Kelompok & Sub Kelompok \\
\hline 1 & $\begin{array}{l}\text { Bahan } \\
\text { Makanan }\end{array}$ & $\begin{array}{l}\text { Padi-padian (Umbi-umbian), Daging, } \\
\text { Ikan Segar, Ikan Diawetkan, Telur dan } \\
\text { Susu, Sayur-Sayuran, Kacang- } \\
\text { Kacangan, Buah-Buahan, Bumbu- } \\
\text { Bumbuan, Lemak dan Minyak, Bahan } \\
\text { Makanan Lainnya }\end{array}$ \\
\hline 2 & $\begin{array}{l}\text { Makanan Jadi, } \\
\text { Minuman, } \\
\text { Rokok Dan } \\
\text { Tembakau }\end{array}$ & $\begin{array}{l}\text { Makanan Jadi, Minuman Yang Tidak } \\
\text { Beralkohol, Tembakau dan Minuman } \\
\text { Beralkohol }\end{array}$ \\
\hline 3 & $\begin{array}{l}\text { Perumahan,Air, } \\
\text { Listrik, Gas } \\
\text { dan Bahan } \\
\text { Bakar }\end{array}$ & $\begin{array}{l}\text { Biaya Tempat Tinggal, Bahan Bakar } \\
\text { (Penerangan) dan Air, Perlengkapan } \\
\text { Rumahtangga, Penyelenggaraan } \\
\text { Rumahtangga }\end{array}$ \\
\hline 4 & Sand & $\begin{array}{l}\text { Sandang Laki-laki, Sandang Wanita, } \\
\text { Sandang Anak-anak, Barang Pribadi } \\
\text { dan Sandang lain }\end{array}$ \\
\hline 5 & Kesehatan & $\begin{array}{l}\text { Jasa Kesehatan, Obat-obatan, Jasa } \\
\text { Perawatan Jasmani, Perawatan } \\
\text { Jasmani dan Kesehatan }\end{array}$ \\
\hline 6 & $\begin{array}{l}\text { Pendidikan, } \\
\text { Rekreasi dan } \\
\text { Olahraga }\end{array}$ & $\begin{array}{l}\text { Jasa Pendidikan, Kursus-kursus / } \\
\text { Pelatihan, Perlengkapan / Peralatan } \\
\text { Pendidikan, Rekreasi Olahraga }\end{array}$ \\
\hline 7 & $\begin{array}{l}\text { Transport, } \\
\text { Komunikasi } \\
\text { dan Jasa } \\
\text { Keuangan }\end{array}$ & $\begin{array}{l}\text { Transport, } \\
\text { Pengiriman, Sarana } \\
\text { Transport, Jasa Keuangan }\end{array}$ \\
\hline
\end{tabular}

Pada penelitian sebelumnya, [8] [10] melakukan penelitian untuk memprediksi Indeks Harga Konsumen (IHK) kelompok bahan

371 Anjar Wanto makanan dengan menggunakan jaringan saraf tiruan backpropagation dan Conjugate Gradient Fletcher Reeves. Penelitian tersebut menghasilkan tingkat akurasi sebesar $75 \%$ apabila menggunakan metode backpropagation, arsitektur terbaik yang digunakan 12-15-1. Sedangkan dengan menggunakan metode Fletcher Reeves menghasilkan tingkat akuras $67 \%$ yang juga menggunakan model arsitektur 12-15-1. Kekurangan dari penelitian ini adalah hasil akurasi yang maksimal karena semakin menurun, yang kemungkinan disebabkan oleh pemilihan arsitektur jaringan yang kurang tepat. Selanjutnya [3] melakukan penelitian untuk memprediksi Indeks Harga Konsumen kelompok kesehatan dengan menggunakan jaringan saraf tiruan backpropagation saja. Penelitian tersebut menghasilkan tingkat akurasi sebesar $92 \%$ dengan arsitektur terbaik 12-70-1. Kekurangan dari penelitian ini adalah hasil akurasi terlalu lama diperoleh serta algoritma yang digunakan hanya menggunakan backpropagation saja, sehingga peneliti tertarik menggunakan metode optimasi agar hasil akurasi cepat diperoleh, tetapi tetap memperhatikan kekonvergenan dengan metode backpropagation standard.

\subsection{Perumusan Masalah}

Perumusan masalah dilakukan untuk menentukan masalah apa saja yang terdapat pada objek penelitian [11]. Perumusan masalah pada penelitian ini adalah sebagai berikut :

1. Backpropagation membutuhkan waktu yang lama dalam proses pembelajaran prediksi data, sehingga dibutuhkan metode yang dapat meningkatan proses pembelajaran.

2. Bagaimana Optimasi Conjugate Gradient Beale-Powell Restarts dari algoritma backpropagation standard untuk prediksi data ? [12].

\subsection{Batasan Masalah}

Agar ruang lingkup masalah yang akan dibahas tidak menjadi luas dan untuk mencapai sasaran dan tujuan yang optimal, maka perlu dilakukan pembatasan masalah, yaitu sebagai berikut :

1. Data yang digunakan adalah data Indeks Harga Konsumen berdasarkan kelompok kesehatan yang bersumber dari Badan Pusat Statistik Kota Medan dari tahun 2014 sampai dengan tahun 2017, bulan Januari sampai dengan bulan Desember.

2. Penelitian dilakukan secara time series dari data IHK kelompok kesehatan yang dilakukan dengan sistem putar (Rotasi).

3. Penelitian menggunakan metode Optimasi Conjugate Gradient Beale-Powell Restarts.

\subsection{Tujuan Penelitian}

Tujuan dari penelitian ini adalah meningkatkan proses pembelajaran prediksi data pada metode backpropagation dengan menggunakan metode Conjugate Gradient Beale-Powell Restarts, agar dihasilkan tingkat akurasi yang lebih cepat dan lebih baik.

\section{TINJAUAN PUSTAKA}

\subsection{Optimasi}

Optimasi adalah suatu usaha atau kegiatan untuk mendapatkan hasil terbaik dengan persyaratan yang diberikan [13]. Menggunakan metode optimasi pada salah satu dari dua https://doi.org/10.25077/ TEKNOSI.v3i3.2017.370-380 
algoritma pembelajaran bertujuan untuk memberikan perbedaan hasil yang diperoleh [14]. Mayoritas algoritma optimasi yang digunakan untuk memecahkan masalah teknik adalah dengan menggunakan metode Conjugate Gradient [15].

\subsection{Prediksi}

Prediksi adalah usaha menduga atau memperkirakan sesuatu yang akan terjadi di waktu mendatang dengan memanfaatkan berbagai informasi yang relevan pada waktu-waktu sebelumnya (historis) melalui suatu metode ilmiah [3].

\subsection{Jaringan Saraf Tiruan (JST)}

Jaringan Saraf Tiruan (JST) adalah metode cerdas dalam komputasi maju yang secara kuantitatif menganalisis informasi dengan belajar dan berlatih, sama seperti sistem kecerdasan manusia [16]. Jaringan Saraf Tiruan merupakan approximator universal fungsi kompleks, yang dapat menangkap hubungan samar antara SNP (Single Nucleotide Polymorphisms) dan nilai fenotipik tanpa memerlukan definisi model genetik secara eksplisit [17].

\subsection{Backpropagation}

Backpropagation adalah model JST yang paling banyak digunakan. Topologi khas backpropagation melibatkan tiga lapisan : lapisan input, dimana data diperkenalkan ke jaringan; lapisan tersembunyi, tempat data diproses dan output layer, dimana hasil input yang diberikan diproduksi [18]. Backpropagation menghitung gradien dari lapisan afermented inference yang hilang menjadi lapisan konvolusi [19].

\subsection{Conjugate Gradient Beale-Powell Restarts}

Metode Conjugate Gradient adalah pendekatan yang sangat efisien dan sederhana dengan penyimpanan rendah, kinerja numerik yang baik dan sifat konvergen global untuk memecahkan masalah optimasi yang tidak terbatas [20]. Conjugate gradient seperti gradient descent juga menggunakan gradien dari fungsi kinerja untuk menentukan pengaturan bobot-bobot dalam rangka meminimumkan fungsi kinerja. Hanya saja conjugate gradient, pengaturan bobot tidak selalu dengan arah menurun tetapi disesuaikan dengan arah konjugasinya [21].

Conjugate Gradient Beale-Powell Restarts (CGB) adalah pelatihan jaringan yang memperbarui nilai bobot dan bias sesuai dengan metode backpropagation. Perhitungan yang dilakukan algoritma backpropagation membutuhkan waktu yang lama dalam proses training, maka digunakan Conjugate Gradient Beale-Powell untuk mempercepat kinerja dari Algoritma Backpropagation. Metode Conjugate Gradient (CG) merupakan salah satu metode optimasi yang arah pencariannya di dasarkan pada arah konjugasi yang nilainya orthogonal [22].

\section{METODOLOGI}

[10] Metodologi penelitian adalah langkah dan prosedur yang akan dilakukan dalam data atau informasi guna memecahkan permasalahan dan menguji hipotesis penelitian. Tahapan-tahapan yang dilakukan dalam penelitian dapat dilihat pada gambar 1 .

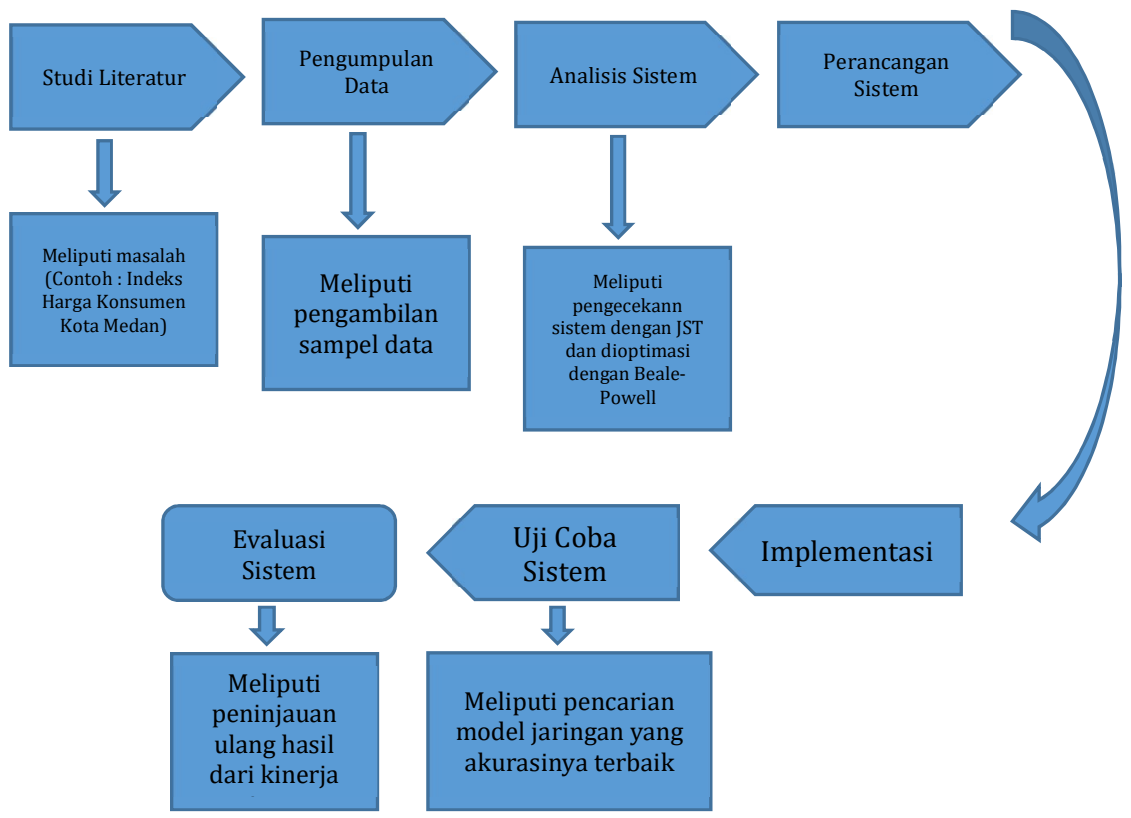

Gambar 1. Metodologi Penelitian

\section{Keterangan :}

Studi literatur yang digunakan untuk menghimpun data-data atau sumber-sumber yang berhubungan dengan topik yang diangkat yang didapat dari berbagai sumber, jurnal, buku dokumentasi maupun internet. Kemudian pengambilan sampel data dari BPS kota Medan, yang nanti nya akan diproses dengan menggunakan
JST (backpropagation dan conjugate gradient beale-powell. Perancangan Sistem berarti merancang input, struktur file, program, prosedur yang diperlukan untuk mendukung sistem informasi. Implementasi adalah suatu tindakan atau pelaksanaan rencana yang telah disusun berdasarkan perancangan sistem. Uji coba sistem merupakan tahapan evaluasi terhadap arsitektur 
sistem yang telah dibangun. Evaluasi Sistem meliputi peninjauan ulang hasil dari kinerja sistem.

\subsection{Proses Pelatihan Dan Pengujian}

Proses pelatihan dan pengujian menggunakan metode Backpropagation dan Conjugate Gradient Beale-Powell Restarts dapat dilihat pada gambar 2 .

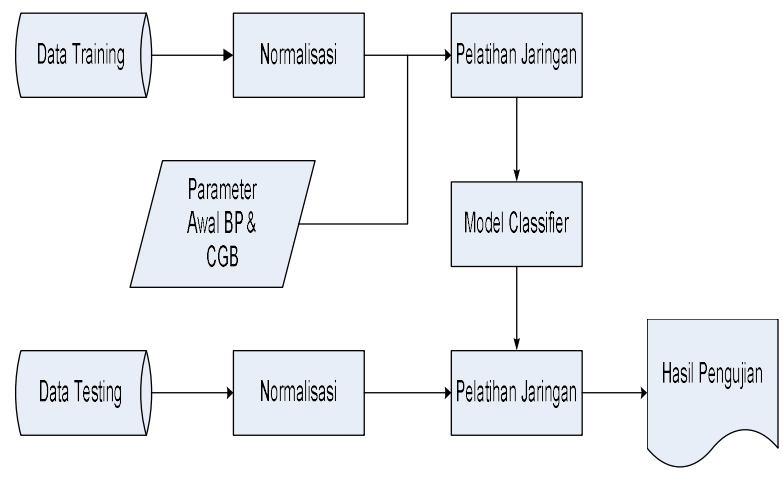

Gambar 2. Proses Training dan Testing

Keterangan :

Pelatihan jaringan menggunakan kedua metode dimulai dengan proses normalisasi data training kemudian parameter awal masing-masing metode ditentukan. Jaringan dilatih hingga membentuk model classifier. Selanjutnya model tersebut diuji menggunakan data testing yang telah dinormalisasi dan menghasilkan hasil pengujian yang dapat diketahui berdasarkan nilai akurasi.

\subsection{Arsitektur Backpropagation}

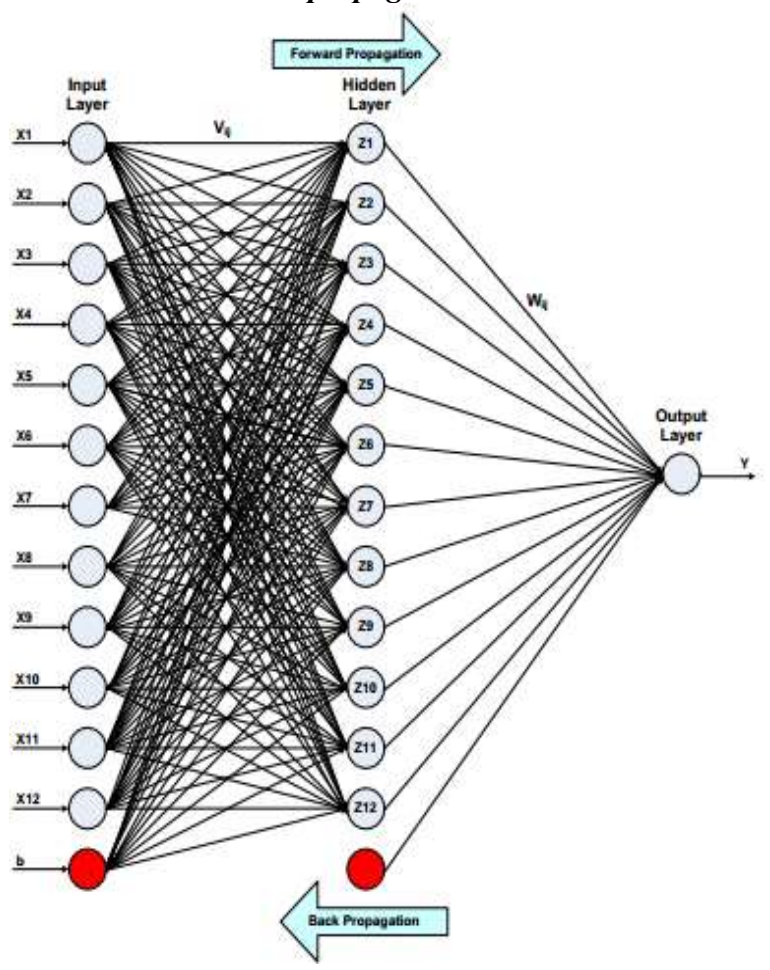

Gambar 3. Arsitektur Backpropagation yang digunakan

Keterangan :
Arsitektur jaringan yang digunakan dapat dilihat pada Gambar 3 yang terdiri dari tiga lapisan, yaitu : 12 masukan (input), 12 neuron (hidden layer) dan 1 lapisan keluaran (output).

\subsection{Pelatihan Standard Backpropagation}

Pelatihan Backpropagation meliputi 3 fase. Fase pertama adalah fase maju. Pola masukan dihitung maju mulai dari layar masukan hingga layar keluaran menggunakan fungsi aktivasi yang ditentukan. Fase kedua adalah fase mundur. Selisih antara keluaran jaringan dengan target yang diinginkan merupakan kesalahan yang terjadi. Kesalahan tersebut dipropagasikan mundur, dimulai dari garis yang berhubungan langsung dengan unit-unit di layar keluaran. Fase ketiga adalah modifikasi bobot untuk menurunkan kesalahan yang terjadi. Berikut langkahlangkah pelatihan dengan backpropagation :

Langkah 0 : Inisialisasi semua bobot dengan bilangan acak kecil. Langkah 1 : Jika kondisi penghentian belum terpenuhi, lakukan langkah 2 sampai dengan 9

Langkah 2 : Untuk setiap pasang data pelatihan, lakukan langkah 3 sampai dengan 8

\section{Fase I: Propagasi Maju}

Langkah 3 : Tiap unit masukkan menerima sinyal dan meneruskannya ke unit tersembunyi

Langkah 4 : Hitung semua keluaran di unit tersembunyi $Z_{j}(j=1$, $2, \ldots, p)$ :

$\mathrm{Z}_{\text {netj }}=\mathrm{V}_{\mathrm{j} 0}+\sum_{i=1}^{n} \mathrm{X}_{\mathrm{i}} \mathrm{V}_{\mathrm{ji}}$

Langkah 5 : Hitung semua jaringan di unit keluaran $\left(\mathrm{Y}_{\mathrm{k}}\right)$

$\mathrm{Y}_{\text {netk }}=\mathrm{W}_{\mathrm{k} 0}+\sum_{j=1}^{p} \mathrm{Z}_{\mathrm{i}} \mathrm{W}_{\mathrm{kj}}$

Fase II : Propagasi Mundur

Langkah 6 : Hitung faktor Sunit keluaran berdasarkan kesalahan di setiap unit keluaran yk $(\mathrm{k}=1,2, \ldots, \mathrm{m})$

$\delta_{\mathrm{k}}=\left(\mathrm{t}_{\mathrm{k}}-\mathrm{y}_{\mathrm{k}}\right) f^{\prime \prime}\left(\mathrm{ynet}_{\mathrm{k}}\right)=\left(\mathrm{t}_{\mathrm{k}}-\mathrm{y}_{\mathrm{k}}\right) \mathrm{y}_{\mathrm{k}}\left(1-\mathrm{y}_{\mathrm{k}}\right)$

Langkah 7 : Hitung penjumlahan kesalahan dari unit tersembunyi $(=\delta)$

$\delta_{\text {netj }}=\sum_{k=1}^{m} \delta_{\mathrm{k}} \mathrm{W}_{\mathrm{kj}}$

\section{Fase III : Perubahan Bobot}

Langkah 8 : Hitung semua perubahan bobot. Perubahan bobot unit keluaran :

$\mathrm{W}_{\mathrm{kj}}($ baru $)=\mathrm{W}_{\mathrm{kj}}($ lama $)+\Delta \mathrm{W}_{\mathrm{kj}}$

Perubahan bobot unit tersembunyi :

$\mathrm{V}_{\mathrm{ji}}($ baru $)=\mathrm{V}_{\mathrm{ji}}($ lama $)+\Delta \mathrm{V}_{\mathrm{ji}}$

\subsection{Algoritma Conjugate Gradient Beale-Powell Restarts}

Conjugate Gradient Beale-Powell Restarts dapat melatih jaringan apapun sepanjang bobot, masukan bersih, dan fungsi transfernya memiliki fungsi turunan. Backpropagation digunakan untuk menghitung derivatif kinerja perf terhadap variabel bobot dan bias X. Setiap variabel disesuaikan sesuai dengan persamaan berikut :

$X=X+a * d X$

dimana $\mathrm{dX}$ adalah arah pencarian. Parameter a dipilih untuk meminimalkan kinerja sepanjang arah pencarian. Fungsi pencarian garis searchFen digunakan untuk menemukan titik minimum. Arah pencarian pertama adalah negatif dari gradien 
kinerja. Dalam iterasi yang berhasil, arah pencarian dihitung dari gradien baru dan arah pencarian sebelumnya sesuai dengan rumus

$\mathrm{dX}=-\mathrm{gX}+\mathrm{dX} \_$old $*$;

dimana gX adalah gradiennya. Parameter $\mathrm{Z}$ dapat dihitung dengan beberapa cara yang berbeda. Variasi Beale- Powell dari gradien konjugasi dibedakan dengan dua ciri. Pertama, algoritma menggunakan tes untuk menentukan kapan harus mereset arah pencarian ke negatif gradien. Kedua, arah pencarian dihitung dari gradien negatif, arah pencarian sebelumnya, dan arah pencarian terakhir sebelum reset sebelumnya. Pelatihan berhenti saat kondisi seperti ini terjadi :

- Jumlah maksimum periode (pengulangan) tercapai.

- Jumlah waktu maksimum terlampaui.

- Kinerja diminimalkan ke tujuan.

- Gradien kinerja turun di bawah min_grad.

- Kinerja validasi telah meningkat lebih dari waktu max_fail sejak terakhir kali menurun (bila menggunakan validasi).

\subsection{Data Yang Digunakan}

Data yang digunakan dalam penelitian ini adalah data Indeks Harga Konsumen (IHK) kelompok kesehatan dari tahun 2014 sampai 2016, dari Januari sampai Desember yang bersumber dari Badan Pusat Statistik Kota Medan. Dataset Indeks Harga Konsumen berdasarkan kelompok kesehatan pada 2014-2015 digunakan sebagai data Training, sedangkan dataset pada 20152016 digunakan sebagai testing data. Data Training dan testing ini nantinya akan dilakukan dengan menggunakan rotasi putar, maksudnya setiap dataset memiliki hak yang sama untuk mencapai target.

Tabel 3. Data Indeks Harga Konsumen Kelompok Kesehatan

\begin{tabular}{cccccc}
\hline \multicolumn{6}{c}{ Indeks Harga Konsumen 2014-2016 } \\
\hline \multirow{5}{*}{ Tahun } & Jan & Feb & $\ldots$ & Nov & Des \\
\cline { 2 - 6 } & $\ldots 3$ B & \\
\hline 2014 & 103,39 & 104,13 & $\ldots$ & 107,24 & 107,73 \\
2015 & 108,28 & 108,63 & $\ldots$ & 114,39 & 114,44 \\
2016 & 117,95 & 118,20 & $\ldots$ & 121,10 & 121,26 \\
\hline (Sumber : Badan Pusat Statistik Pematangsiantar)
\end{tabular}

\subsection{Normalisasi Data}

Normalisasi terhadap data dilakukan agar keluaran jaringan sesuai dengan fungsi aktivasi yang digunakan. Fungsi aktivasi yang peneliti gunakan dalam penelitian ini adalah fungsi aktivasi sigmoid. Fungsi sigmoid adalah fungsi asimtotik (tidak pernah mencapai 0 ataupun 1), maka transformasi data dilakukan pada interval yang lebih kecil yaitu [0.1;0.9], ditunjukkan dengan persamaan berikut :

$x^{\prime}=\frac{0.8(x-a)}{b-a}+0.1$

- Data Training Tahun 2014-2015 dilakukan dengan menggunakan rotasi putar, maksudnya setiap dataset memiliki hak yang sama untuk mencapai target.

- Nilai data 1 diambil dari IHK kelompok kesehatan tahun 2014. Sedangkan nilai Target diambil dari IHK kelompok kesehatan bulan Januari tahun 2015.

- Nilai data 2 diambil dari IHK kelompok kesehatan tahun 2014 bulan Februari s/d Desember serta dataset bulan Januari tahun
2015. Nilai Target pada pola 2 ini diambil dari IHK kelompok kesehatan bulan Februari tahun 2015.

- Nilai data 3 diambil dari IHK kelompok kesehatan tahun 2014 bulan Maret s/d Desember serta dataset bulan Januari s/d Februari tahun 2015. Nilai Target pada pola 3 ini diambil dari IHK kelompok kesehatan bulan Maret tahun 2015.

- Begitu seterusnya hingga seluruh nilai selesai di putar.

- Nilai maksimum (b) dari dataset adalah 114,44. Sedangkan nilai minimum (a) adalah 103,39.

Tabel 4. Data Training Awal Sebelum Normalisasi

\begin{tabular}{ccccccc}
\hline \multirow{2}{*}{ Data } & \multicolumn{5}{c}{ Input } \\
\cline { 2 - 6 } & Jan & Feb & $\ldots$ & Nov & Des & \\
\hline Pola 1 & 103,39 & 104,13 & $\ldots$ & 105,40 & 105,46 & 108,28 \\
Pola 2 & 104,13 & 105,26 & $\ldots$ & 105,46 & 105,55 & 108,63 \\
Pola 3 & 105,26 & 105,40 & $\ldots$ & 105,55 & 106,53 & 109,46 \\
Pola 4 & 105,40 & 105,46 & $\ldots$ & 106,53 & 106,88 & 109,58 \\
Pola 5 & 105,46 & 105,55 & $\ldots$ & 106,88 & 107,04 & 110,09 \\
Pola 6 & 105,55 & 106,53 & $\ldots$ & 107,04 & 107,16 & 112,34 \\
Pola 7 & 106,53 & 106,88 & $\ldots$ & 107,16 & 107,24 & 113,23 \\
Pola 8 & 106,88 & 107,04 & $\ldots$ & 107,24 & 107,73 & 113,31 \\
Pola 9 & 107,04 & 107,16 & $\ldots$ & 107,73 & 108,28 & 113,65 \\
Pola 10 & 107,16 & 107,24 & $\ldots$ & 108,28 & 108,63 & 114,10 \\
Pola 11 & 107,24 & 107,73 & $\ldots$ & 108,63 & 109,46 & 114,39 \\
Pola 12 & 107,73 & 108,28 & $\ldots$ & 109,46 & 109,58 & 114,44 \\
\hline
\end{tabular}

- Dengan menggunakan fungsi sigmoid maka akan di peroleh data normalisasi sebagai berikut :

$$
x^{\prime}=\frac{0,8(103,39-103,39)}{114,44-103,39}+0,1
$$

Maka akan didapatkan hasil Normalisasi pola 1 untuk bulan Januari 0,1000 . Begitu seterusnya untuk semua data, di normalisasi dengan menggunakan fungsi yang sama.

Tabel 5. Data Training Setelah Normalisasi

\begin{tabular}{ccccccc}
\hline \multirow{2}{*}{ Data } & \multicolumn{5}{c}{ Input } & \multirow{2}{*}{ Target } \\
\cline { 2 - 6 } & Jan & Feb & $\ldots$ & Nov & Des & \\
\hline Pola 1 & 0,1000 & 0,1536 & $\ldots$ & 0,3787 & 0,4142 & 0,4540 \\
Pola 2 & 0,1536 & 0,2354 & $\ldots$ & 0,4142 & 0,4540 & 0,4794 \\
Pola 3 & 0,2354 & 0,2455 & $\ldots$ & 0,4540 & 0,4794 & 0,5395 \\
Pola 4 & 0,2455 & 0,2499 & $\ldots$ & 0,4794 & 0,5395 & 0,5481 \\
Pola 5 & 0,2499 & 0,2564 & $\ldots$ & 0,5395 & 0,5481 & 0,5851 \\
Pola 6 & 0,2564 & 0,3273 & $\ldots$ & 0,5481 & 0,5851 & 0,7480 \\
Pola 7 & 0,3273 & 0,3527 & $\ldots$ & 0,5851 & 0,7480 & 0,8124 \\
Pola 8 & 0,3527 & 0,3643 & $\ldots$ & 0,7480 & 0,8124 & 0,8182 \\
Pola 9 & 0,3643 & 0,3729 & $\ldots$ & 0,8124 & 0,8182 & 0,8428 \\
Pola 10 & 0,3729 & 0,3787 & $\ldots$ & 0,8182 & 0,8428 & 0,8754 \\
Pola 11 & 0,3787 & 0,4142 & $\ldots$ & 0,8428 & 0,8754 & 0,8964 \\
Pola 12 & 0,4142 & 0,4540 & $\ldots$ & 0,8754 & 0,8964 & 0,9000 \\
\hline
\end{tabular}

\subsection{Pelatihan Standard Backpropagation}

- Data testing Tahun 2015-2016 dilakukan dengan menggunakan rotasi putar, maksudnya setiap dataset memiliki hak yang sama untuk mencapai target. 
- Nilai data 1 diambil dari IHK kelompok kesehatan tahun 2015. Sedangkan nilai Target diambil dari IHK kelompok kesehatan bulan Januari tahun 2016.

- Nilai data 2 diambil dari IHK kelompok kesehatan tahun 2015 bulan Februari s/d Desember serta dataset bulan Januari tahun 2016. Nilai Target data 2 ini diambil dari IHK kelompok kesehatan bulan Februari tahun 2016.

- Nilai data 3 diambil dari IHK kelompok kesehatan tahun 2015 bulan Maret s/d Desember serta dataset bulan Januari s/d Februari tahun 2016. Nilai Target data 3 ini diambil dari IHK kelompok kesehatan bulan Maret tahun 2016.

- Begitu seterusnya hingga seluruh nilai selesai di putar.

- Nilai maksimum (b) dari dataset adalah 121,26. Sedangkan nilai minimum (a) adalah 108,28.

Tabel 6. Data Testing Awal Sebelum Normalisasi

\begin{tabular}{ccccccc}
\hline \multirow{2}{*}{ Data } & \multicolumn{7}{c}{ Input } & \\
\cline { 2 - 6 } & Jan & Feb & $\ldots$ & Nov & Des & \\
\hline Pola 13 & 108,28 & 108,63 & $\ldots$ & 114,39 & 114,44 & 117,95 \\
Pola 14 & 108,63 & 109,46 & $\ldots$ & 114,44 & 117,95 & 118,20 \\
Pola 15 & 109,46 & 109,58 & $\ldots$ & 117,95 & 118,20 & 118,37 \\
Pola 16 & 109,58 & 110,09 & $\ldots$ & 118,20 & 118,37 & 118,48 \\
Pola 17 & 110,09 & 112,34 & $\ldots$ & 118,37 & 118,48 & 119,03 \\
Pola 18 & 112,34 & 113,23 & $\ldots$ & 118,48 & 119,03 & 119,13 \\
Pola 19 & 113,23 & 113,31 & $\ldots$ & 119,03 & 119,13 & 113,23 \\
Pola 20 & 113,31 & 113,65 & $\ldots$ & 119,13 & 113,23 & 120,62 \\
Pola 21 & 113,65 & 114,10 & $\ldots$ & 113,23 & 120,62 & 120,73 \\
Pola 22 & 114,10 & 114,39 & $\ldots$ & 120,62 & 120,73 & 121,00 \\
Pola 23 & 114,39 & 114,44 & $\ldots$ & 120,73 & 121,00 & 121,10 \\
Pola 24 & 114,44 & 117,95 & $\ldots$ & 121,00 & 121,10 & 121,26 \\
\hline
\end{tabular}

- Dengan menggunakan fungsi sigmoid maka akan di dapat data normalisasi sebagai berikut :

$$
x^{\prime}=\frac{0,8(108,28-108,28)}{121,26-108,28}+0,1
$$

Maka akan didapatkan hasil Normalisasi 1 untuk bulan Januari 0,1000 . Begitu seterusnya untuk semua data, di normalisasi dengan menggunakan fungsi yang sama.

Tabel 7. Data Testing Setelah Normalisasi

\begin{tabular}{ccccccc}
\hline \multirow{2}{*}{ Data } & \multicolumn{7}{c}{ Input } \\
\cline { 2 - 6 } & Jan & Feb & $\ldots$ & Nov & Des & \\
\hline Pola 13 & 0,1000 & 0,1216 & $\ldots$ & 0,4766 & 0,4797 & 0,6960 \\
Pola 14 & 0,1216 & 0,1727 & $\ldots$ & 0,4797 & 0,6960 & 0,7114 \\
Pola 15 & 0,1727 & 0,1801 & $\ldots$ & 0,6960 & 0,7114 & 0,7219 \\
Pola 16 & 0,1801 & 0,2116 & $\ldots$ & 0,7114 & 0,7219 & 0,7287 \\
Pola 17 & 0,2116 & 0,3502 & $\ldots$ & 0,7219 & 0,7287 & 0,7626 \\
Pola 18 & 0,3502 & 0,4051 & $\ldots$ & 0,7287 & 0,7626 & 0,7687 \\
Pola 19 & 0,4051 & 0,4100 & $\ldots$ & 0,7626 & 0,7687 & 0,4051 \\
Pola 20 & 0,4100 & 0,4310 & $\ldots$ & 0,7687 & 0,4051 & 0,8606 \\
Pola 21 & 0,4310 & 0,4587 & $\ldots$ & 0,4051 & 0,8606 & 0,8673 \\
Pola 22 & 0,4587 & 0,4766 & $\ldots$ & 0,8606 & 0,8673 & 0,8840 \\
Pola 23 & 0,4766 & 0,4797 & $\ldots$ & 0,8673 & 0,8840 & 0,8901 \\
Pola 24 & 0,4797 & 0,6960 & $\ldots$ & 0,8840 & 0,8901 & 0,9000 \\
\hline
\end{tabular}

Langkah pertama yang dilakukan untuk memprogram backpropagation dengan Matlab adalah membuat inisialisasi jaringan. Sebelum Training dilakukan, terlebih dahulu ditentukan nilai parameter yang diinginkan guna memperoleh hasil yang optimal. Arsitektur menggunakan 1 hidden layer, 12 neuron input, 8 neuron hidden $(5,26,29,35,40,60,70,75)$, fungsi aktivasi sigmoid, minimum error $0.001-0.05$ serta learning rate 0.01 .

\subsection{Analisis}

Data yang akan diujikan haruslah dibagi menjadi dua (2) bagian, bagian pertama untuk data training, bagian kedua untuk data testing. Parameter-parameter yang digunakan secara umum pada aplikasi Matlab dengan algoritma backpropagation standard dapat dilihat pada kode berikut :

$>>$ net=newff(minmax $(\mathrm{P}),[$ Hidden, Target], \{'logsig','purelin'\},'tra ingd');

$>$ net.IW $\{1,1\}$;

$>$ net.b $\{1\}$;

$>$ net.LW $\{2,1\}$;

$>$ net.b $\{2\}$;

$>$ net.trainparam.epochs $=10000$;

$>>$ net.trainparam. $\mathrm{LR}=0.01$

$>>$ net.trainParam.goal $=0.001$;

$>>$ net.trainParam.show $=1000$;

$>>$ [a,Pf,Af,e,Perf] $=\operatorname{sim}($ net,P,[],[],T)

Sedangkan dengan metode Conjugate Gradient Beale-Powell Restarts :

$>>$ net=newff(minmax $(P),[$ Hidden,Target], \{'tansig','logsig'\},'trai $n c g b ')$;

$>$ net.IW $\{1,1\}$

$>>$ net.b $\{1\}$

$>$ net.LW $\{2,1\}$

$>>$ net.b $\{2\}$

$>>$ net.trainParam .epochs $=5000000$;

$>>$ net.trainParam.goal $=0.001$;

$>>$ net.trainParam.show $=1000$;

$>$ net $=$ train $($ net $, P, T)$

$>>[a, P f, A f, e, P e r f]=\operatorname{sim}($ net,, , [],[],T)

$>>[$ a,Pf,Af,e,Perf $]=\operatorname{sim}($ net,P,[],[],T)

\subsection{Hasil}

Penelitian ini menggunakan 8 model arsitektur. Antara lain 12-51, 12-26-1, 12-29-1, 12-35-1, 12-40-1, 12-60-1, 12-70-1, 12-751. Masing-masing model arsitektur jaringan diproses dengan menggunakan Algoritma backpropagation dan metode Conjugate Gradient Beale-Powell Restarts. 


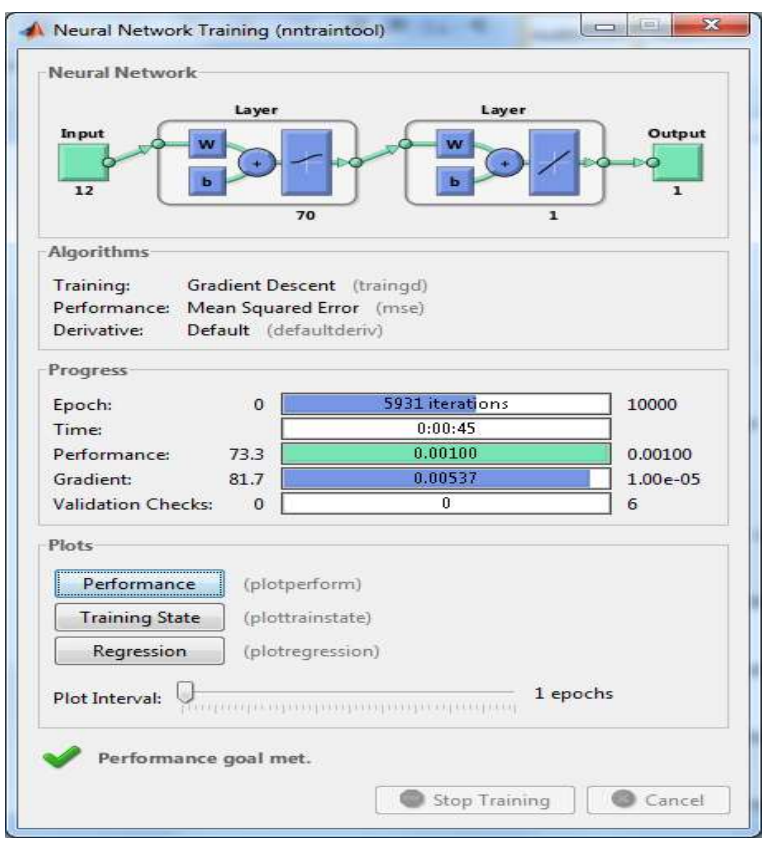

Gambar 4. Hasil Training 12-70-1 dengan backpropagation

Keterangan :

Dari gambar model arsitektur 12-70-1 diatas dapat dijelaskan bahwa Epoch yang terjadi sebesar 5931 dengan lama waktu 45 detik.

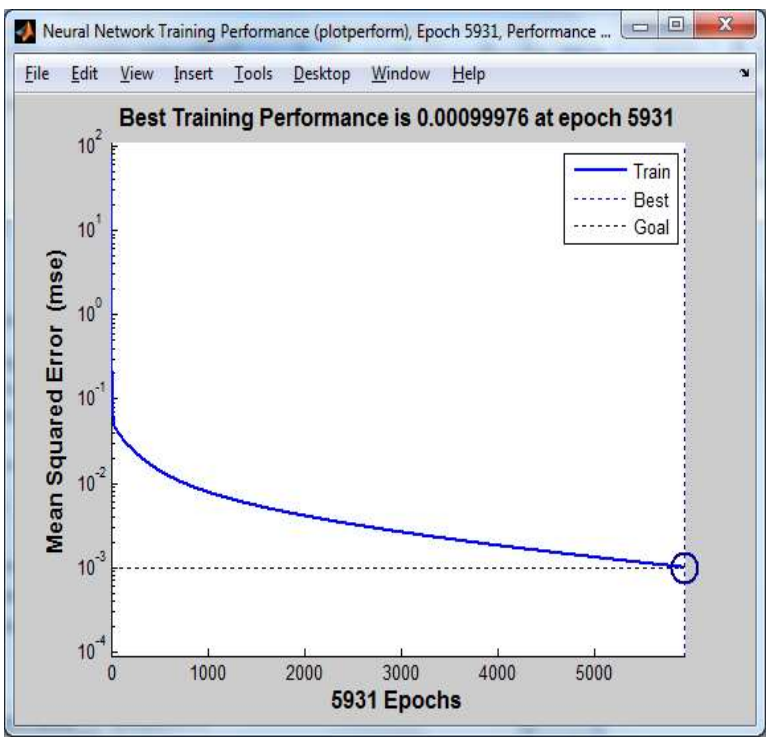

Gambar 5. Hasil Epoch Training Dengan Arsitektur 12-70-1

\section{Keterangan :}

Dari gambar 5 dijelaskan bahwa dari Epoch training dapat diperoleh Mean Square Error (MSE) sebesar 0,00099976.

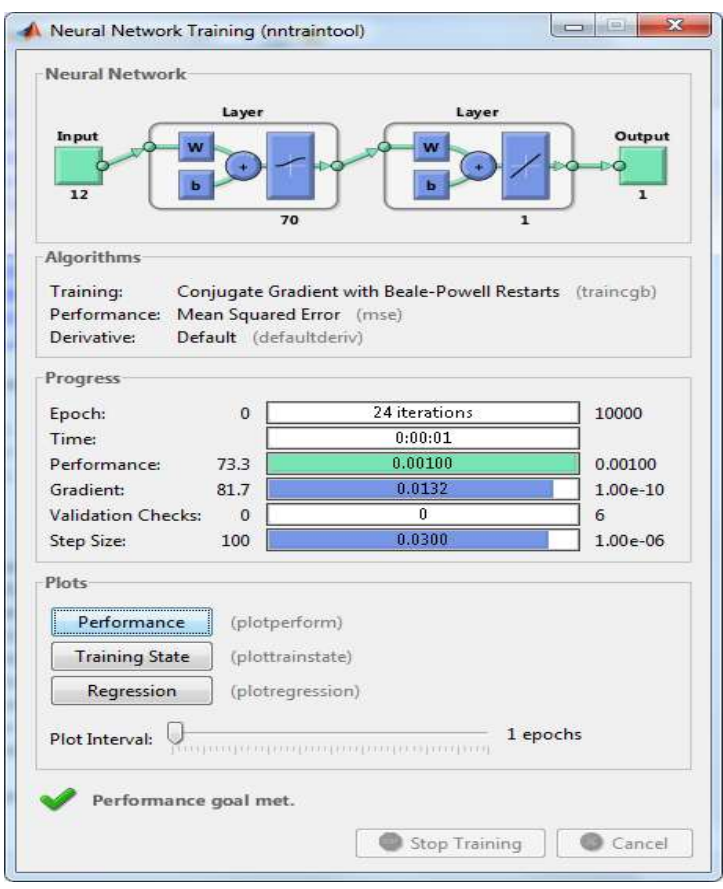

Gambar 6. Hasil Training 12-70-1 dengan beale-powell

Keterangan :

Dari gambar model arsitektur 12-70-1 dengan conjugate gradient beale-powell restarts diatas dapat dijelaskan bahwa Epoch yang terjadi sebesar 24 iterasi dengan lama waktu 1 detik.

Pada tabel 8 akan dijabarkan model arsitektur terbaik (12-70-1) dengan menggunakan algoritma backpropagation, dengan tingkat akurasi sebesar 92\%. Keterangan Prediksi ( 1 = Benar, $0=$ Salah).

Tabel 8. Hasil Training Dan Testing Algoritma Backpropagation Pada Arsitektur 12-70-1

\begin{tabular}{|c|c|c|c|c|c|c|c|c|}
\hline \multicolumn{9}{|c|}{ Backpropagation (12-70-1) } \\
\hline \multicolumn{4}{|c|}{ Data Training } & \multicolumn{5}{|c|}{ Data Testing } \\
\hline Target & Output & Error & SSE & Target & Output & Error & SSE & Prediksi \\
\hline 0,45403 & 0,47250 & $-0,01847$ & 0,000341 & 0,69599 & 0,84010 & $-0,14411$ & 0,020767 & 1 \\
\hline 0,47937 & 0,44640 & 0,03297 & 0,001087 & 0,71140 & 1,33360 & $-0,62220$ & 0,387130 & 1 \\
\hline 0,53946 & 0,57120 & $-0,03174$ & 0,001008 & 0,72188 & 0,76760 & $-0,04572$ & 0,002090 & 1 \\
\hline 0,54814 & 0,52970 & 0,01844 & 0,000340 & 0,72866 & 1,35150 & $-0,62284$ & 0,387930 & 1 \\
\hline 0,58507 & 0,57340 & 0,01167 & 0,000136 & 0,76256 & 1,37800 & $-0,61544$ & 0,378769 & 1 \\
\hline 0,74796 & 0,74870 & $-0,00074$ & 0,000001 & 0,76872 & 1,12160 & $-0,35288$ & 0,124524 & 1 \\
\hline 0,81240 & 0,85170 & $-0,03930$ & 0,001545 & 0,40508 & 1,04950 & $-0,64442$ & 0,415271 & 1 \\
\hline 0,81819 & 0,76170 & 0,05649 & 0,003191 & 0,86055 & 1,08860 & $-0,22805$ & 0,052005 & 1 \\
\hline 0,84281 & 0,89420 & $-0,05139$ & 0,002641 & 0,86733 & 1,93220 & $-1,06487$ & 1,133939 & 1 \\
\hline 0,87538 & 0,83910 & 0,03628 & 0,001317 & 0,88398 & 1,54580 & $-0,66182$ & 0,438012 & 1 \\
\hline 0,89638 & 0,91570 & $-0,01932$ & 0,000373 & 0,89014 & 1,89280 & $-1,00266$ & 1,005330 & 1 \\
\hline \multirow[t]{3}{*}{0,90000} & 0,89580 & 0,00420 & 0,000018 & 0,90000 & 0,68570 & 0,21430 & 0,045924 & 0 \\
\hline & & Total & 0,011997 & & & Total & 4,391691 & \\
\hline & & MSE & 0,001000 & & & MSE & 0,365974 & \\
\hline
\end{tabular}


Model arsitektur terbaik dengan menggunakan Algoritma Backpropagation yang dioptimasi dengan Conjugate Gradient Beale-Powell Restarts adalah 12-70-1, dengan tingkat akurasi sebesar 92\%. Keterangan Prediksi $(1=$ Benar, $0=$ Salah $)$.

Tabel 9. Hasil Algoritma Backpropagation Dengan Conjugate Gradient Beale-Powell Restarts Pada Arsitektur 12-70-1

\begin{tabular}{cc|}
\hline Backpropagation + Conjugate Gradient Beale-Powell Restarts (12-70-1) \\
\hline Data Training & Data Testing \\
\hline
\end{tabular}

Target Output Error SSE Target Output Error SSE Prediksi

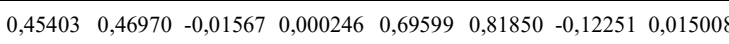

$\begin{array}{llllllll}0,47937 & 0,44790 & 0,03147 & 0,000990 & 0,71140 & 1,29770 & -0,58630 & 0,343745\end{array}$

$\begin{array}{llllllll}0,53946 & 0,55830 & -0,01884 & 0,000355 & 0,72188 & 0,74950 & -0,02762 & 0,000763\end{array}$

$\begin{array}{lllllllll}0,54814 & 0,51400 & 0,03414 & 0,001166 & 0,72866 & 1,34450 & -0,61584 & 0,379260\end{array}$

$\begin{array}{llllllll}0,58507 & 0,58660 & -0,00153 & 0,000002 & 0,76256 & 1,41720 & -0,65464 & 0,428556\end{array}$

$\begin{array}{llllllll}0,74796 & 0,75850 & -0,01054 & 0,000111 & 0,76872 & 1,15150 & -0,38278 & 0,146520\end{array}$

$\begin{array}{lllllllll}0,81240 & 0,85180 & -0,03940 & 0,001553 & 0,40508 & 1,04270 & -0,63762 & 0,406553\end{array}$

$\begin{array}{lllllllll}0,81819 & 0,75800 & 0,06019 & 0,003623 & 0,86055 & 1,10500 & -0,24445 & 0,059754\end{array}$

$\begin{array}{llllllll}0,84281 & 0,87570 & -0,03289 & 0,001082 & 0,86733 & 1,91670 & -1,04937 & 1,101168\end{array}$

$\begin{array}{llllllll}0,87538 & 0,85680 & 0,01858 & 0,000345 & 0,88398 & 1,55450 & -0,67052 & 0,449603\end{array}$

$\begin{array}{llllllll}0,89638 & 0,94220 & -0,04582 & 0,002099 & 0,89014 & 1,85990 & -0,96976 & 0,940437\end{array}$

$\begin{array}{llllllll}0,90000 & 0,87930 & 0,02070 & 0,000428 & 0,90000 & 0,70170 & 0,19830 & 0,039323\end{array}$

\begin{tabular}{lllll} 
Total & 0,012001 & Total & 4,310690 & \\
${$\cline { 2 - 3 }$} }$ & $\mathbf{0 , 0 0 1 0 0 0}$ & MSE & $\mathbf{0 , 3 5 9 2 2 4}$ &
\end{tabular}

Hasil tingkat akurasi dari ke 8 model arsitektur yang digunakan sangat bervariasi, begitu juga dengan epoch (iterasi) dan waktu training. Pada tabel 10 akan dijabarkan seberapa besar tingkat keakurasian dari masing-masing model arsitektur dengan menggunakan algoritma backpropagation standard.

Tabel 10. Tingkat akurasi 8 model arsitektur dengan menggunakan algoritma backpropagation standard.

\begin{tabular}{cccccc}
\hline \multicolumn{5}{c}{ Backpropagation Standard } \\
\hline \multirow{2}{*}{$\begin{array}{c}\text { Model } \\
\text { Arsitektur }\end{array}$} & \multicolumn{3}{c}{ Training } & \multicolumn{2}{c}{ Testing } \\
\cline { 2 - 6 } & Epoch & Waktu & MSE & MSE & Akurasi \\
\hline $12-5-1$ & 2243 & $00: 17$ & 0,000999 & 0,043463 & $58 \%$ \\
$12-26-1$ & 6409 & $00: 42$ & 0,001000 & 0,205866 & $58 \%$ \\
$12-29-1$ & 9551 & $01: 02$ & 0,001001 & 0,310441 & $75 \%$ \\
$12-35-1$ & 5770 & $00: 37$ & 0,001001 & 0,891477 & $50 \%$ \\
$12-40-1$ & 5963 & $00: 37$ & 0,001000 & 0,447132 & $42 \%$ \\
$12-60-1$ & 3904 & $00: 24$ & 0,001000 & 0,245978 & $67 \%$ \\
$\mathbf{1 2 - 7 0 - 1}$ & $\mathbf{5 9 3 1}$ & $\mathbf{0 0 : 4 5}$ & $\mathbf{0 , 0 0 1 0 0 0}$ & $\mathbf{0 , 3 6 5 9 7 4}$ & $\mathbf{9 2 \%}$ \\
$12-75-1$ & 3231 & $00: 24$ & 0,001000 & 0,468078 & $50 \%$ \\
\hline
\end{tabular}

Sedangkan hasil tingkat akurasi dari ke 8 model arsitektur dengan menggunakan Backpropagation yang telah dioptimasi dengan conjugate gradient Beale-Powell Restarts dapat dilihat pada tabel 11.

Anjar Wanto
Tabel 11. Tingkat akurasi 8 model arsitektur algoritma backpropagation + conjugate gradient beale-powell restarts

\begin{tabular}{cccccc}
\hline \multicolumn{3}{c}{ Backpropagation With Beale-Powell Restarts } \\
\hline $\begin{array}{c}\text { Model } \\
\text { Arsitektur }\end{array}$ & \multicolumn{3}{c}{ Training } & \multicolumn{2}{c}{ Testing } \\
\cline { 2 - 6 } & Epoch & Waktu & MSE & MSE & Akurasi \\
\hline $12-5-1$ & 5 & $00: 01$ & 0,000511 & 0,036117 & $58 \%$ \\
$12-26-1$ & 13 & $00: 01$ & 0,000855 & 0,198203 & $58 \%$ \\
$12-29-1$ & 21 & $00: 01$ & 0,000815 & 0,270300 & $75 \%$ \\
$12-35-1$ & 15 & $00: 01$ & 0,000837 & 0,863388 & $42 \%$ \\
$12-40-1$ & 12 & $00: 01$ & 0,000900 & 0,434351 & $42 \%$ \\
$12-60-1$ & 14 & $00: 01$ & 0,000947 & 0,238910 & $67 \%$ \\
$\mathbf{1 2 - 7 0 - 1}$ & $\mathbf{2 4}$ & $\mathbf{0 0 : 0 1}$ & $\mathbf{0 , 0 0 1 0 0 0}$ & $\mathbf{0 , 3 5 9 2 2 4}$ & $\mathbf{9 2 \%}$ \\
$12-75-1$ & 19 & $00: 01$ & 0,000687 & 0,449641 & $50 \%$ \\
\hline
\end{tabular}

Berdasarkan keterangan tabel 10 dan tabel 11, maka dapat disimpulkan bahwa epoch (iterasi) maupun waktu training dengan menggunakan Conjugate Gradient Beale-Powell Restarts lebih cepat. Untuk lebih jelasnya dapat dilihat pada tabel 12 berikut :

Tabel 12. Perbandingan epoch algoritma backpropagation + conjugate gradient beale-powell restarts

\begin{tabular}{ccc}
\hline \multirow{2}{*}{$\begin{array}{c}\text { Model } \\
\text { Arsitektur }\end{array}$} & \multicolumn{2}{c}{ Epoch (Iterasi) } \\
\cline { 2 - 3 } & Backpropagation & $\begin{array}{c}\text { Backpropagation + } \\
\text { Beale-Powell }\end{array}$ \\
\hline $12-5-1$ & 2243 & 5 \\
$12-26-1$ & 6409 & 13 \\
$12-29-1$ & 9551 & 21 \\
$12-35-1$ & 5770 & 15 \\
$12-40-1$ & 5963 & 12 \\
$12-60-1$ & 3904 & 14 \\
$\mathbf{1 2}-\mathbf{7 0 - 1}$ & $\mathbf{5 9 3 1}$ & $\mathbf{2 4}$ \\
$12-75-1$ & 3231 & 19 \\
\hline
\end{tabular}

Berdasarkan keterangan tabel 10 dan tabel 11 juga, maka dapat disimpulkan bahwa tingkat akurasi Conjugate Gradient BealePowell Restarts konvergen dengan backpropagation. Untuk lebih jelasnya dapat dilihat pada tabel 13 berikut :

Tabel 13. Perbandingan tingkat akurasi algoritma backpropagation + conjugate gradient beale-powell restarts

\begin{tabular}{ccc}
\hline \multirow{2}{*}{$\begin{array}{c}\text { Model } \\
\text { Arsitektur }\end{array}$} & \multicolumn{2}{c}{ Tingkat Akurasi } \\
\cline { 2 - 3 } & Backpropagation & $\begin{array}{c}\text { Backpropagation + } \\
\text { Beale-Powell }\end{array}$ \\
\hline $12-5-1$ & $58 \%$ & $58 \%$ \\
$12-26-1$ & $58 \%$ & $58 \%$ \\
$12-29-1$ & $75 \%$ & $75 \%$ \\
$12-35-1$ & $50 \%$ & $42 \%$ \\
$12-40-1$ & $42 \%$ & $42 \%$ \\
$12-60-1$ & $67 \%$ & $67 \%$ \\
$\mathbf{1 2 - 7 0 - 1}$ & $\mathbf{9 2 \%}$ & $\mathbf{9 2 \%}$ \\
$12-75-1$ & $50 \%$ & $50 \%$ \\
\hline
\end{tabular}

https://doi.org/10.25077/ TEKNOSI.v3i3.2017.370-380 
Berdasarkan tabel 12 dan tabel 13, maka dapat digambarkan grafik dari kedua algoritma (backpropagation dan conjugate gradient beale-powell restarts).

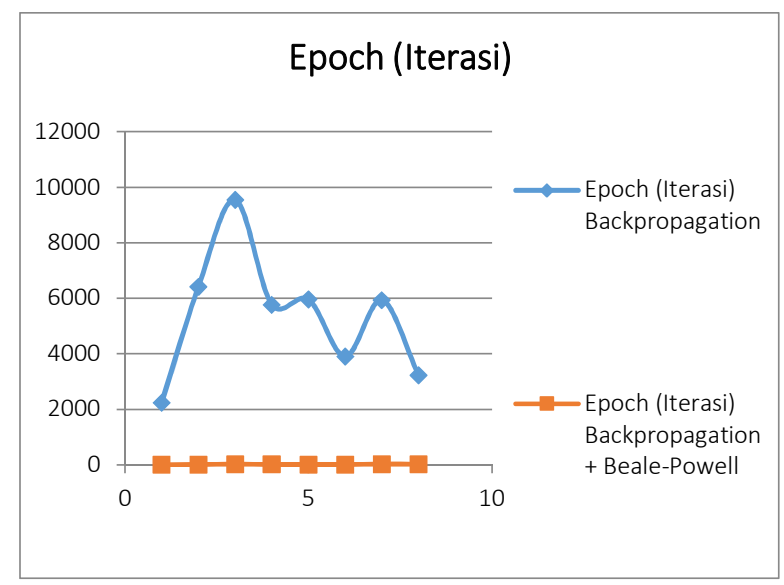

Gambar 7. Perbandingan Epoch (Iterasi) dari kedua metode

Keterangan :

Dari Gambar 5 dapat jelas diketahui, bahwa dengan menggunakan metode Conjugate Gradient Beale-Powell Restarts, maka epoch (iterasi) yang terjadi sangat kecil, sehingga hasil akurasi lebih cepat diperoleh. Sedangkan dengan menggunakan algoritma backpropagation standard, epoch (iterasi) yang terjadi sangat besar, yakni mencapai \pm 10.000 , sehingga tingkat akurasi yang dihasilkan lebih lama. Oleh karena itu optimasi dengan conjugate gradient beale-powell restarts terbukti efektif.

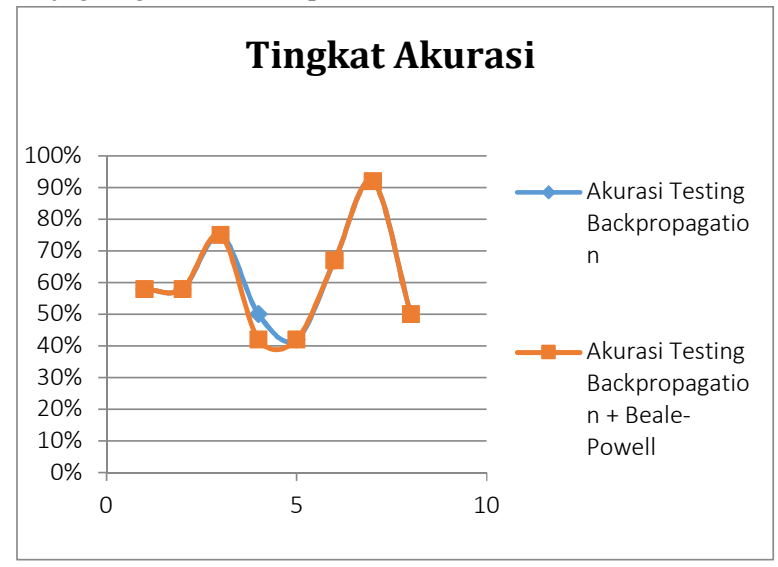

Gambar 8. Perbandingan Tingkat Akurasi dari kedua metode

Keterangan :

Dapat dilihat pada gambar 6, bahwa tingkat akurasi dari masingmasing model arsitektur yang terbaik (12-70-1) baik menggunakan Backpropagation standard maupun yang sudah dioptimasi dengan conjugate gradient beale-powell restarts, sama-sama menghasilkan tingkat akurasi sebesar 92\%. Dengan kata lain bahwa algoritma backpropagation konvergen dengan conjugate gradient beale-powell restarts karena hasil akurasi sesuai dengan yang diinginkan, yakni mendekati $100 \%$.

Dari proses training dan testing yang sudah dilakukan pada algoritma backpropagation dengan menggunakan optimasi conjugate gradient beale-powell restarts, maka diperoleh lah hasil prediksi data Indeks Harga Konsumen Tahun 2017 dan 2018

https://doi.org/10.25077/ TEKNOSI.v3i3.2017.370-380 bulan Januari sampai dengan bulan Desember. Pada Tabel 14 untuk prediksi Tahun 2017, Data real diperoleh dari Indeks Harga Konsumen (IHK) tahun 2016. Target diperoleh dari data testing metode conjugate gradient beale-powell restarts, bukan data testing backpropagation. Target Prediksi diperoleh dari output perhitungan di Matlab dengan menggunakan rumus : >> [a,Pf,Af,e,Perf] $=\operatorname{sim}($ net,P,[],[],T). Sedangkan Prediksi diperoleh dari :

$\frac{(\text { TargetPrediksi-0,1)*(max_DataReal-min_DataReal })}{0,8}+$ min_DataReal

Tabel 14. Prediksi Tahun 2017

\begin{tabular}{ccccc}
\hline \multicolumn{5}{c}{ Prediksi Tahun 2017 } \\
\hline \multirow{2}{*}{ Bulan } & $\begin{array}{c}\text { Data } \\
\text { Real }\end{array}$ & Target & $\begin{array}{c}\text { Target } \\
\text { Prediksi }\end{array}$ & Prediksi \\
\hline 1 & 117,95 & 0,69599 & 0,64790 & 118,73 \\
2 & 118,20 & 0,71140 & 0,78290 & 120,08 \\
3 & 118,37 & 0,72188 & 0,69440 & 119,20 \\
4 & 118,48 & 0,72866 & 0,71440 & 119,40 \\
5 & 119,03 & 0,76256 & 0,80030 & 120,26 \\
6 & 119,13 & 0,76872 & 0,72910 & 119,54 \\
7 & 113,23 & 0,40508 & 0,42300 & 116,47 \\
8 & 120,62 & 0,86055 & 0,87290 & 120,99 \\
9 & 120,73 & 0,86733 & 0,86140 & 120,87 \\
10 & 121,00 & 0,88398 & 0,88390 & 121,10 \\
11 & 121,10 & 0,89014 & 0,89460 & 121,21 \\
12 & 121,26 & 0,90000 & 0,89060 & 121,17 \\
\hline
\end{tabular}

Pada Tabel 15 untuk prediksi Tahun 2018, Data real diperoleh dari Indeks Harga Konsumen (IHK) tahun 2017. Target diperoleh dari data testing metode conjugate gradient beale-powell restarts, bukan data testing backpropagation. Target Prediksi diperoleh dari output perhitungan di Matlab dengan menggunakan rumus : $>>$ a,Pf,Af,e,Perf] $=$ sim(net,P,[],[],T). Prediksi diperoleh dari :

$\frac{(\text { TargetPrediksi }-0,1) *(\text { max_DataReal }- \text { min_DataReal })}{0,8}+$ min_DataReal

Tabel 15. Prediksi Tahun 2018

\begin{tabular}{ccccc}
\hline \multicolumn{5}{c}{ Prediksi Tahun 2018 } \\
\hline Bulan & $\begin{array}{c}\text { Data } \\
\text { Real }\end{array}$ & Target & $\begin{array}{c}\text { Target } \\
\text { Prediksi }\end{array}$ & Prediksi \\
\hline 1 & 118,73 & 0,64790 & 0,64390 & 119,71 \\
2 & 120,08 & 0,78290 & 0,80560 & 120,51 \\
3 & 119,20 & 0,69440 & 0,65510 & 119,99 \\
4 & 119,40 & 0,71440 & 0,73800 & 120,11 \\
5 & 120,26 & 0,80030 & 0,77760 & 120,62 \\
6 & 119,54 & 0,72910 & 0,73970 & 120,19 \\
7 & 116,47 & 0,42300 & 0,44110 & 118,38 \\
8 & 120,99 & 0,87290 & 0,84270 & 121,05 \\
9 & 120,87 & 0,86140 & 0,92130 & 120,98 \\
10 & 121,10 & 0,88390 & 0,82680 & 121,11 \\
11 & 121,21 & 0,89460 & 0,91830 & 121,17 \\
12 & 121,17 & 0,89060 & 0,88670 & 121,15 \\
\hline & & & \multicolumn{2}{c}{ Anjar Wanto 378}
\end{tabular}


Tabel 16.a dan Tabel 16.b adalah hasil prediksi yang telah dicapai berdasarkan pada Tabel 14 dan Tabel 15. Pada Tabel 16.a berisikan hasil prediksi Indeks Harga Konsumen (IHK) Tahun 2017-2018 (berwarna kuning), bulan Januari sampai dengan Juni.

Tabel 16.a. Hasil Prediksi Data Indeks Harga Konsumen (IHK) Tahun 2017-2018

\begin{tabular}{ccccccc}
\hline \multirow{2}{*}{ Tahun } & \multicolumn{6}{c}{ Bulan } \\
\cline { 2 - 7 } & Jan & Feb & Mar & Apr & Mei & Jun \\
\hline 2014 & 103,39 & 104,13 & 105,26 & 105,40 & 105,46 & 105,55 \\
2015 & 108,28 & 108,63 & 109,46 & 109,58 & 110,09 & 112,34 \\
2016 & 117,95 & 118,20 & 118,37 & 118,48 & 119,03 & 119,13 \\
2017 & 118,73 & 120,08 & 119,20 & 119,40 & 120,26 & 119,54 \\
2018 & 119,71 & 120,51 & 119,99 & 120,11 & 120,62 & 120,19 \\
\hline
\end{tabular}

Tabel 16.b adalah hasil prediksi Indeks Harga Konsumen (IHK) Tahun 2017-2018, bulan Juli-Desember

Tabel 16.b. Hasil Prediksi Data Indeks Harga Konsumen (IHK) Tahun 2017-2018

\begin{tabular}{ccccccc}
\hline \multirow{2}{*}{ Tahun } & \multicolumn{6}{c}{ Bulan } \\
\cline { 2 - 7 } & Jul & Agu & Sep & Okt & Nov & Des \\
\hline 2014 & 106,53 & 106,88 & 107,04 & 107,16 & 107,24 & 107,73 \\
2015 & 113,23 & 113,31 & 113,65 & 114,10 & 114,39 & 114,44 \\
2016 & 113,23 & 120,62 & 120,73 & 121,00 & 121,10 & 121,26 \\
2017 & 116,47 & 120,99 & 120,87 & 121,10 & 121,21 & 121,17 \\
2018 & 118,38 & 121,05 & 120,98 & 121,11 & 121,17 & 121,15 \\
\hline
\end{tabular}

\section{KESIMPULAN DAN SARAN}

\subsection{Kesimpulan}

Kesimpulan yang dapat diambil dari penelitian ini antara lain :

1. Model arsitektur terbaik dengan menggunakan algoritma backpropagation maupun ketika sudah dioptimasi dengan conjugate gradient beale-powell restarts adalah sama, yakni model 12-70-1.

2. Hasil akurasi dengan menggunakan backpropagation standard adalah sebesar 92\%, sedangkan setelah dioptimasi dengan conjugate gradient beale-powell restarts juga sebesar $92 \%$. Dengan demikian hasil akurasi terbaik dari kedua metode tersebut konvergen, karena hasilnya sama. Sedangkan dengan menggunakan 7 model arsitektur yang lain, persentase hasil akurasi juga tidak terlalu jauh bahkan relatif sama.

3. Optimasi Algoritma Backpropagation dengan Conjugate Gradient Beale-powell Restarts terbukti dapat diimplementasikan untuk memprediksi data times series, khususnya untuk memprediksi Indeks Harga Konsumen (IHK) berdasarkan kelompok kesehatan

\subsection{Saran}

Adapun saran yang penulis dapat sampaikan dari penelitian ini adalah :

1. Penentuan model arsitektur jaringan yang akan digunakan sangat menentukan hasil tingkat akurasi [23], sehingga diperlukan studi lebih lanjut mengenai penentuan model arsitektur yang terbaik.

2. Penelitian ini masih belum sempurna, terutama tingkat keakurasian. Sehingga perlu dilakukan penelitian lebih lanjut dengan menggunakan metode atau algoritma optimasi lain untuk mendapatkan hasil yang lebih baik lagi.

\section{DAFTAR PUSTAKA}

[1] L. Handayani and M. Adri, "Penerapan JST ( Backpropagation ) untuk Prediksi Curah Hujan ( Studi Kasus: Kota Pekanbaru )," Seminar Nasional Teknologi Informasi, Komunikasi dan Industri (SNTIKI) 7, no. November, pp. 238-247, 2015.

R. Hrasko, A. G. C. Pacheco, and R. A. Krohling, "Time Series Prediction Using Restricted Boltzmann Machines and Backpropagation," Procedia Computer Science, vol. 55, no. Itqm, pp. 990-999, 2015.

[3] A. Wanto and A. P. Windarto, "Analisis Prediksi Indeks Harga Konsumen Berdasarkan Kelompok Kesehatan Dengan Menggunakan Metode Backpropagation," Sinkron Jurnal \& Penelitian Teknik Informatika, vol. 2, pp. 37-43, 2017.

R. Y. Fa'rifah and Z. Busrah, "Backpropagation Neural Network Untuk Optimasi Akurasi Pada Prediksi Financial Distress Perusahaan," Jurnal INSTEK, vol. 2, no. April, pp. 101-110, 2017.

[5] I. Muzakkir, A. Syukur, and I. N. Dewi, "Backpropagation Dengan Seleksi Fitur Particle Swarm Optimization Dalam Prediksi Pelanggan Telekomunikasi," Jurnal Pseudocode, vol. 1, pp. 1-10, 2014.

[6] N. Aditiarini, "Metode Gradien Konjugat Dalam Menyelesaikan Masalah Optimasi Menggunakan Aplikasi Android," Skripsi , Institut Pertanian Bogor, 2017.

[7] K. S. Madhavan, "Knowledge Based Prediction through Artificial Neural Networks and Evolutionary Strategy for Power Plant Applications," Journal of Scientific and Engineering Research, vol. 4, no. 9, pp. 371-376, 2017.

[8] A. Wanto, M. Zarlis, Sawaluddin, D. Hartama, J. T. Hardinata, and H. F. Silaban, "Analysis of Artificial Neural Network Backpropagation Using Conjugate Gradient Fletcher Reeves In The Predicting Process," International Conference on Information and Communication Technology (IconICT), pp. 1-7, 2017.

[9] M. S. Frits Fahridws Damanik, SST and S. Magdalena Sinaga, "Analisis Indeks Harga Konsumen (IHK) Kota Pematangsiantar," Sensus 
Ekonomi, 2014.

[10] A. Wanto, "Analisis Jaringan Saraf Tiruan Backpropagation Menggunakan Conjugate Gradient Fletcher Reeves Dalam Proses Memprediksi," Tesis, Universitas Sumatera Utara, 2017.

[11] E. P. Cynthia and E. Ismanto, "Jaringan Syaraf Tiruan Algoritma Backpropagation Dalam Memprediksi Ketersediaan Komoditi Pangan Provinsi Riau," Seminar Nasional Teknologi Informasi, Komunikasi dan Industri (SNTIKI) 9, pp. 18-19, 2017.

[12] H. Y. Sari, “Optimasi Conjugate Gradient Pada Algoritma Backpropagation Neural Network Untuk Prediksi Kurs Time Series," Jurnal Gema Aktualita, vol. 5, no. 1, pp. 86-90, 2016.

[13] I. G. P. Arka, "Kajian Analisis Perfomansi Sistem Fire Alarm Dengan Mode Addresable dan Non Addresable Menggunakan Algoritma Genetika," Jurnal Matrix, vol. 4, no. 1, pp. 33-34, 2014.

[14] M. R. Lubis, "Metode Hybrid Particle Swarm Optimization - Neural Network Backpropagation Untuk Prediksi Hasil Pertandingan Sepak Bola," Jurnal Sains Komputer \& Informatika (J-SAKTI), no. 1, pp. 71-83, 2017.

[15] S. Mirjalili, P. Jangir, S. Z. Mirjalili, S. Saremi, and I. N. Trivedi, "Optimization of problems with multiple objectives using the multi-verse optimization algorithm," Knowledge-Based Systems, 2017.

[16] A. Ehret, D. Hochstuhl, D. Gianola, and G. Thaller, "Application of neural networks with backpropagation to genome-enabled prediction of complex traits in Holstein-Friesian and German Fleckvieh cattle," Genetics Selection Evolution, vol. 47, no. 1, p. 22, 2015.

[17] R. Olawoyin, "Application of backpropagation artificial neural network prediction model for the PAH bioremediation of polluted soil," Jurnal Chemosphere, vol. 161, pp. 145-150, 2016.

[18] D. Huang and Z. Wu, "Forecasting outpatient visits using empirical mode decomposition coupled with backpropagation artificial neural networks optimized by particle swarm optimization," PLoS $O N E$, vol. 12, no. 2, pp. 1-18, 2017.

[19] P. Witoonchart and P. Chongstitvatana, "Structured SVM Backpropagation To Convolutional Neural Network Applying To Human Pose Estimation," Journal of LATEX, vol. 92, pp. 39-46, 2017.

[20] B. Keshtegar, "Limited conjugate gradient method https://doi.org/10.25077/ TEKNOSI.v3i3.2017.370-380 for structural reliability analysis," Engineering with Computers, vol. 33, no. 3, 2017.

[21] Y. Sari, F. D. Marleny, R. Ansari, M. Izzana, A. P. Ricardus, and B. Lareno, "Optimasi Conjugate Gradient Pada Backpropagation Neural Network untuk Deteksi Kualitas Daun Tembakau," Konferensi Nasional Sistem \& Informatika, pp. 910, 2015.

[22] U. N. Wisesty, I. Parwati, and Adiwijaya, "Deteksi Anomali pada Intrusion Detection System (IDS) Menggunakan Algoritma Backpropagation Termodifikasi Conjugate Gradient Polak Ribiere," Indosc 2016, no. August, pp. 165-176, 2016.

[23] A. Wanto, A. P. Windarto, D. Hartama, and I. Parlina, "Use of Binary Sigmoid Function And Linear Identity In Artificial Neural Networks For Forecasting Population Density," International Journal Of Information System \& Technology (IJISTECH), vol. 1, no. 1, pp. 43-54, 2017.

\section{BIODATA PENULIS}

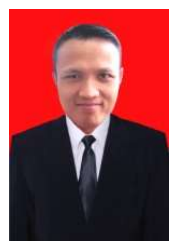

Anjar Wanto

Lahir di Bah Jambi 14 Februari 1985. Sekolah Dasar pada SD No. 095201 Emplasmen Bah Jambi Sumatera Utara. Sekolah tingkat pertama pada SLTP Taman Siswa Bah Jambi. Sekolah tingkat atas pada SMK Negeri 2 Pematangsiantar Sumatera Utara. Mengenyam pendidikan D-3 di AMIK Tunas Bangsa Pematangsiantar. S-1 pada Sekolah Tinggi Teknik (STT) Poliprofesi Medan dan S-2 dari Fakultas Ilmu Komputer dan Teknologi Informasi Universitas Sumatera Utara (USU) Program Studi Teknik Informatika. Saat ini penulis merupakan Dosen Tetap pada AMIK dan STIKOM Tunas Bangsa Pematangsiantar yang sekaligus sebagai Koordinator Penelitian pada Lembaga Penelitian dan Pengabdian Pada Masyarakat (LPPM) pada Perguruan Tinggi tersebut. 